BNL-108455-2015-JA

\title{
Synchrotron micro-scale study of trace metal transport and distribution in Spartina alterniflora root system in Yangtze River intertidal zone
}

Huan Feng ${ }^{1 *}$, Weiguo Zhang ${ }^{2}$, Wenliang Liu $^{2}$, Lizhong $\mathrm{Yu}^{2}$, Yu Qian ${ }^{1}$, Jun Wang ${ }^{3}$, Jia-Jun

Wang ${ }^{3}$, Christopher Eng ${ }^{3}$, Chang-Jun Liu ${ }^{4}$, Keith W. Jones ${ }^{4}$, Ryan Tappero ${ }^{3}$

1. Department of Earth and Environmental Studies, Montclair State University, Montclair, New Jersey 07043, USA

2. State Key Laboratory of Estuarine and Coastal Research, East China Normal University, Shanghai 200062, PRC

3. Photon Sciences Directorate, Brookhaven National Laboratory, Upton, New York 11973, USA

4. Biological, Environmental \& Climate Sciences Department, Brookhaven National Laboratory, Upton, New York 11973, USA

* Corresponding author.

E-mail address: fengh@mail.montclair.edu; Tel: 1-973-655-7549; Fax: 1-973-655-4072.

\begin{abstract}
:
This study is focused on micro-scale measurement of metal (Ca, Cl, Fe, $\mathrm{K}, \mathrm{Mn}, \mathrm{Cu}, \mathrm{Pb}$ and $\mathrm{Zn)}$ distributions in Spartina alterniflora root system. The root samples were collected in the Yangtze River intertidal zone in July 2013. Synchrotron X-ray fluoresces (XRF), computed tomography (CMT) and absorption near edge structure (XANES) techniques, which provide
\end{abstract}


micro-meter scale analytical resolution, were applied to this study. Although it was found that the metals of interest were distributed in both epidermis and vascular tissue with the varying concentrations, the results showed that Fe plaque was mainly distributed in the root epidermis. Other metals (e.g., $\mathrm{Cu}, \mathrm{Mn}, \mathrm{Pb}$ and $\mathrm{Zn}$ ) were correlated with Fe in the epidermis possibly due to scavenge by Fe plaque. Relatively high metal concentrations were observed in the root hair tip. This micro-scale investigation provides insights of understanding the metal uptake and spatial distribution as well as the function of Fe plaque governing metal transport in the root system.

Keywords: Spartina alterniflora; Trace metals; Synchrotron radiation technique; Rhizosphere root system; Transport; Yangtze River estuary

\section{Introduction}

Previous studies have shown that wetland plants can uptake heavy metals from rhizosphere soils and sediments through the root system and store these metals within the plant biomass (Williams et al., 1994; Lacerda et al., 1997; Tangahu et al., 2011; Koelmel and Amarasiriwardena 2012). Significant correlations between metal concentrations in plants and that in the surrounding soils were also found (Cheng, 2003; Weis and Weis, 2004; Rotkittikhum et al., 2006; Qian et al., 2012; Lyubenova et al., 2013). However, very limited high resolution information is available on metal uptake, distribution and transport processes in the plants. In the meantime, the function of Fe plaque that is predominantly Fe oxides in metal uptake by the plants is still not well understood despite Fe plaque has been identified as a buffer or barrier that capable of enhancing or reducing plant metal uptake efficiency in many studies (Tripathi et al.,

2014). Some studies suggest that the Fe plaque on the root surface serves as a barrier preventing 
metals from entering plant roots (e.g., St-Cyr and Campbell, 1996; Sundby et al. 1998), while others argue that Fe plaque is not the main barrier (e.g., Ye et al. 1998; Liu et al. 2004). More information is needed to make broad inferences in this aspect. Therefore, investigation of the natural processes that control the metal translocation in wetland plants is critical to understand metal biogeochemical cycle. Spartina alterniflora, which takes up and accumulates metals during its growth (Windham et al., 2003), is a dominant wetland species in the Yangtze River intertidal zone. Because of its geographical location next to one of the world's largest urban area and within one of the world's largest estuarine system, the wetland in Yangtze River intertidal zone is a unique test bed for examination of metal uptake by wetland plants. The synchrotronbased techniques with high detection sensitivity and analytical resolution for elemental composition measurement have been employed by the environmental science community (Jones and Feng, 2002; Sutton et al., 2002; Punshon et al., 2009; Jones et al., 2013). In this study, synchrotron radiation techniques are applied to investigate metal transport and distributions in Spartina alterniflora root as well as the function of Fe plaque in metal scavenge in the root system. This research certainly improves our current knowledge of metal distributions and transport in the wetland plants.

\section{Materials and Methods}

\section{Study area}

The Yangtze River estuary, which is one of the largest estuaries in the world, is defined as a mesotidal estuary with a mean tidal range of $2.6 \mathrm{~m}$ and a mean spring tidal range of $4.0 \mathrm{~m}$. 
Under the fair weather conditions, the Yangtze River estuary is dominantly influenced by tides that affect the estuarine water circulation and sediment deposition. The channel on the north side of Chongming Island, where the study site is located, is flood-tide dominated, while the channel on the south side of Chongming Island is ebb-tide dominated. There is evidence showing that there exists lateral residual circulation in the estuary, making water and sediment exchanges between the channels in the estuary (e.g., Wu et al., 2010). Huge amount of sediments $\left(\sim 4.86 \times 10^{8}\right.$ ton $\left.\mathrm{y}^{-1}\right)$ have been discharged from the Yangtze River annually, resulting in an extensive intertidal zone in the Yangtze River estuary (Chen, 1998). This well-developed intertidal zone typically contains three distinct vegetation units seaward: a Phragmites australis zone, a Scirpus mariqueter and Scirpus trigueter zone, and bare unvegetated mudflats (Zhang et al., 2001). In late 1990s, Spartina alterfloria was planted on Jiuduansha Shoal as well as the eastern end of Chongming Island for promotion of sediment accretion and coastal defense. It is now becoming a predominant species in the area. Urbanization and economic development in Shanghai, which is the largest city in China and located next to the Yangtze River estuary, have a direct impact on the Yangtze River estuary. Industrial and domestic sewage are discharged into the Yangtze River estuary (Dai and Gu, 1990). In addition to the local waste discharge, many land areas in or adjacent to the intertidal zone are used for commercial harbors, iron and steel mills, and other industrial operations (Chen et al., 2007). Previous studies have shown that environmental quality in the Yangtze River estuary has been degraded due to urbanization and industrial development in Shanghai metropolitan area (Feng et al. 2004; Liu et al., 2006; Zhang et al. 2009).

\section{$\underline{\text { Sample collection and preparation }}$}


Spartina alterniflora replicate samples were collected in the Yangtze River intertidal

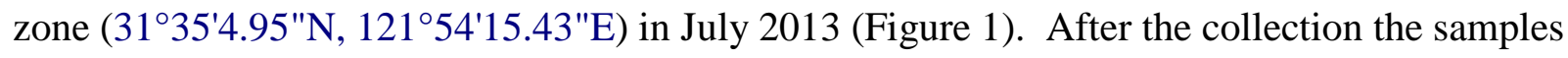
were placed in a large plastic container and then transported immediately to East China Normal University in Shanghai for further laboratory treatment. Bulk sediments on the roots were removed by hand. The trace residual sediments on the roots were rinsed off gently with small amount ( $<20 \mathrm{ml}$ ) of deionized water. Some of the fresh root samples were processed immediately for analysis. The others were oven dried separately at $30^{\circ} \mathrm{C}$ and archived for future analysis. For synchrotron CMT analysis, a dried clean section of $2 \mathrm{~cm}$ long root sample was put in a Kapton tube $(\Phi<1 \mathrm{~mm})$, sealed on both ends and put on a stand for the analysis (Jones et al., 2013). The cleaned fresh root samples for synchrotron XRF measurement were suspended in an optimal cutting temperature (OCT) compound that does not infiltrate the specimen, and cooled at $-20^{\circ} \mathrm{C}$. Once OCT solidified, a cryotome (Cryostat CM1950, Leica Microsystems) was used to cut a $50 \mu \mathrm{m}$ thin section and then mounted on a $25 \mathrm{~mm} \times 76 \mathrm{~mm}$ quartz microscope slide (SPI Supplies $^{\circledR}$ ) (Feng et al., 2013). For synchrotron XANES measurement, a portion ( 1mm long) of dry root samples was sectioned and mounted on a needle stand for the analysis. Before the analysis, all these samples were kept in our specially designed biology laboratory with a temperature control at $4^{\circ} \mathrm{C}$ or a desiccator.

Synchrotron X-ray computed tomography (CMT), fluorescence (XRF), and absorption near edge structure (XANES) measurement

Synchrotron CMT measurement was made at X2B beamline in the National Synchrotron Light Source (NSLS) at Brookhaven National Laboratory (BNL) in Upton, New York, USA 
(Jones et al., 2005, 2013). The tomography apparatus uses a Si $(1,1,1)$ monochromator to produce a monoenergetic beam of $10.0 \mathrm{keV}$. A beam size of about $6 \mathrm{~mm} \times 6 \mathrm{~mm}$ was used to irradiate the root sample contained in the Kapton tube. The beam transmitted through the sample was detected with a CsI (Tl) scintillator. Light from the scintillator was magnified and then imaged with a CCD camera with 1340 x 1300 pixels of $4 \mu \mathrm{m}$ size. The tomographic volume was produced from a collection of 1200 images taken in $0.15^{\circ}$ steps. The volume was produced using the tomo_display software (http://cars.uchicago.edu/software/IDL/tomography.html). The analysis and visualization was achieved with the ImageJ package (http://imagej.nih.gov/ij/). Elemental (Ca, $\mathrm{Cl}, \mathrm{Cu}, \mathrm{Fe}, \mathrm{K}, \mathrm{Mn}, \mathrm{Pb}$ and $\mathrm{Zn})$ concentrations and distributions in the root tissue were investigated using synchrotron XRF technique at NSLS X27A beamline (Ablett et al. 2006; Feng et al., 2013). Briefly, this bend magnet beamline uses Kirkpatrick-Baez (K-B) mirrors to produce a focused spot (10 $\mu \mathrm{m} \times 10 \mu \mathrm{m})$ of hard X-rays with tunable energy achieved via Si(111) or $\mathrm{Si}(311)$ channel-cut monochromator crystals. For synchrotron XRF imaging, the incident beam energy was fixed at $13.5 \mathrm{keV}$ to excite all target elements simultaneously. The sample was oriented at $45^{\circ}$ to the incident beam, and rastered in the path of the beam by an XY stage while X-ray fluorescence was detected by a 13-element Canberra Ge array detector positioned at $90^{\circ}$ to the incident beam. Elemental maps were typically collected from a $1 \mathrm{~mm}^{2}$ sample area using a step size of $15 \mu \mathrm{m}$ and a dwell time of 7 seconds. The fluorescence yields were normalized to the changes in intensity of the X-ray beam $\left(\mathrm{I}_{0}\right)$ and the dwell time. Synchrotron X-ray absorption near edge structure (XANES) measurement was conducted at NSLS X8C beamline that was equipped with a full-field transmission X-ray microscope (TXM) manufactured by Xradia, Inc (Wang et al., 2012; Jones et al. 2013). The newly developed TXM provides a large field of view (40 $\mu \mathrm{m} \times 40 \mu \mathrm{m}$ ), $30 \mathrm{~nm}$ resolution, local tomography, and automated maker-free image 
acquisition and alignment (Wang et al., 2012, 2014a). By tuning X-ray energy across the absorption edge of the element of interesting, this TXM technique enables chemical information with high sensitivity (Wang et al., 2014b). In order to investigate Fe distribution in the roots, the XANES data were collected by scanning the X-ray energy from $7092 \mathrm{eV}$ to $7192 \mathrm{eV}$ with a step size of $2 \mathrm{eV}$ in this study. A stack of images was obtained by scanning the photon energy across the X-ray absorption edge of elemental Fe. A lens-coupled scintillator with a $2048 \times 2048$ pixel camera detector was used to record images. With all $1024 \times 1024$ pixels for bin $2 \times 2$, the full spectrum for each pixel was extracted. The XANES analysis was carried out using a customized program (MatLab, MathWorks, R2011b) developed in house (Beamline X8C group, NSLS, BNL). Background normalization was carried out first for TXM images with a unique background image collected at every energy. More information about TXM and XANES can be found in Wang et al. (2013, 2014b). A tomographic dataset was collected using 361 projections at a range between $-90^{\circ}$ to $+90^{\circ}(2 \times 2$ camera pixels with $10 \mathrm{~s}$ exposure time). The reconstruction and visualization of the experimental data were accomplished using a proprietary software developed by Xradia, Inc.

\section{$\underline{\text { Data extraction for statistical analysis }}$}

In order to investigate factors governing the metal transport and accumulation and to avoid excessive data processing, we selected 2-3 sub-areas in the epidermis and one broad sub-area in the vascular tissue within the plant root section (Figures 2a, 2b) as well as one area in the root hair tip (Figure 2c). Data acquisition was made from two-dimensional (2D) scan or mapping and data in sub-areas were extracted and used for the statistical analysis. Each sub-area in the 
epidermis contained 30 to 90 points measured for metal concentrations. There were a total of 484 points in the epidermis among the three samples, which were used for statistical analysis. In the vascular bundle, each sub-area contained 110 to 130 points measured for the metal concentrations. There were a total of 372 points selected in the vascular tissue among the three samples for statistical analysis. The sub-area in the root hair tip section contained 152 points for statistical analysis. Each sub-area in the root tissue showed a range of metal concentrations.

\section{$\underline{\text { Statistical analysis }}$}

Student t-test analysis was performed on the data to examine metal concentration differences between epidermis and vascular tissue of each plant root. Factor analysis and hierarchical cluster analysis were also performed on the data. Logarithmic transformation of the data was made before the analysis to ensure a normal distribution (Gotelli and Ellison 2004). In factor analysis, varimax rotation was applied to maximize the sum of the variance of the factor coefficients. In hierarchical clustering analysis, single linkage method (nearest neighbor) and Pearson correlation (distance) were applied in the analysis.

\section{Results}

\section{Microscale tomographic root structure and metal concentrations in the root tissue}

Three-dimensional (3D) visualization of tomographic Spartina alterfloria root structure is shown in Figure 3. High attenuation substances are seen in epidermis. Although the chemical composition of the high attenuation substance cannot be identified in this study by the current 
synchrotron CMT measurement, synchrotron XRF measurement confirms that $\mathrm{Cl}, \mathrm{Ca}, \mathrm{K}, \mathrm{Fe}, \mathrm{Mn}$, $\mathrm{Cu}, \mathrm{Pb}$ and $\mathrm{Zn}$ are concentrated within these substances. Figure 4 shows these metal concentrations and distributions in the root cross-section from epidermis to vascular tissue. It is seen that $\mathrm{Fe}$ and $\mathrm{Pb}$ have relatively much higher concentrations in the epidermis than that in the vascular tissue, forming a nearly continuous, surficial rind on the root exterior (Figure 4).

Among the other elements ( $\mathrm{Ca}, \mathrm{Cl}, \mathrm{K}, \mathrm{Mn}, \mathrm{Cu}$ and $\mathrm{Zn}$ ), which are essential nutrients for the plant growth, $\mathrm{Cl}$, Mn and $\mathrm{Zn}$ show relatively higher concentrations in the epidermis than that in the vascular tissue, while Ca shows relatively higher concentration in the vascular tissue than that in the epidermis (Figure 4). The concentrations of $\mathrm{Cu}$ and $\mathrm{K}$ in the epidermis and vascular tissue are comparable (Figure 4). It is interestingly observed that very high metal concentrations are present in the root hair tip (Figure 4). It is well known that the function of root hairs is to take up water and mineral nutrients present in the sediments and transport these nutrients through the roots to the rest of the plant (McLaughlin et al., 1998; Hinsinger et al., 2008; Marques, et al., 2009).

Table 1 summarizes the range and average of element/metal concentrations in all the selected sub-areas within the epidermis, vascular tissue and root hair tip. In general, $\mathrm{Cl}, \mathrm{Fe}, \mathrm{Mn}, \mathrm{Pb}$ and Zn have higher average concentrations in the epidermis than that in the vascular tissue while Ca has higher average concentration in the vascular tissue than that in the epidermis. Average concentrations of $\mathrm{Cu}$ and $\mathrm{K}$ are comparable between the epidermis and vascular tissue. Except $\mathrm{Cl}$ and $\mathrm{K}$, metals have higher average concentrations in the root hair tip than that in the main root (Table 1).

\section{$\underline{\text { Statistical analysis }}$}


To examine the differences in metal concentrations between the epidermis and the vascular tissue and between the root and root hair tip in the cross-section of the same sample, Student $t$ test was performed on the data. Significant differences $(p<0.01)$ were found in all the cases except for $\mathrm{Cu}(p=0.372)$ and $\mathrm{K}(p=0.098)$ between the epidermis and the vascular tissue. The results suggest that the uptake mechanisms by plants and transport pathways within the plant tissues could be different for different metals. In addition, both factor analysis and hierarchical cluster analysis were applied to the data analysis (Gotelli and Ellison 2004). In factor analysis, the root tissues were divided into three groups (epidermis, vascular tissue and root hair tip) and analyzed separately. As shown in Table 2, four factors in the epidermis with eigenvalue greater than 0.5 account for $86 \%$ of the total variance. Factor 1 has high loadings of Ca (0.865) and moderate loadings of $\mathrm{Zn}(0.680), \mathrm{Mn}(0.561)$ and $\mathrm{Fe}(0.495)$ and explains $24 \%$ of the variance (Table 2). This factor is a Ca factor and reflects the association of these metals (Ca, Fe, Mn and $\mathrm{Zn})$ as nutrients in the epidermis. Factor 2 has high loadings of $\mathrm{Cl}(0.893)$ and $\mathrm{K}(0.882)$ and accounts for $23 \%$ of the variance. Although both $\mathrm{Cl}$ and $\mathrm{K}$ are nutrients for the plants, they are also major elements in sea water. This factor may reflect salt tolerance on Spartina alterfloria. As a saltmarsh species, Spartina alterfloria can uptake $\mathrm{Cl}$ and $\mathrm{K}$ in seawater and, hence, grow up in estuarine system. Factor 3, which has a high loading of $\mathrm{Cu}(0.980)$, is essentially a $\mathrm{Cu}$ controlling factor and accounts for $13 \%$ of total variance. Factor 4 has high loadings of $\mathrm{Pb}$ (0.905) and Fe (0.732) and moderate loadings of Mn (0.600) and Zn (0.457) and explains 26\% of total variance. This factor reflects metal ( $\mathrm{Pb}, \mathrm{Mn}$ and $\mathrm{Zn})$ scavenging by or adsorption on $\mathrm{Fe}$ plaque and co-precipitation of $\mathrm{Pb}$ and $\mathrm{Zn}$ with Fe-Mn oxides. In vascular tissue, there are seven factors which have an eigenvalue greater than 0.5 and account for $98 \%$ of total variance (Table 
2). Factor 1 has high loadings of $\mathrm{K}$ (0.931) and $\mathrm{Cl}$ (0.917) and explains 23\% of total variance. This factor also reflects sea salt influence on salt water Spartina alterfloria in the estuarine system. Factors 2-7 have high loadings of $\mathrm{Cu}$ (0.979), $\mathrm{Pb}$ (0.994), Fe (0.970), Zn (0.994), Ca (0.967) and Mn (0.950), respectively, and almost equally explain the total variance (12-13\%) (Table 2). These factors are essentially individual factors of $\mathrm{Cu}, \mathrm{Pb}, \mathrm{Fe}, \mathrm{Zn}, \mathrm{Ca}$ and $\mathrm{Mn}$ and control the transport and distribution of these metals in vascular tissue. In the root hair tip section, there are three factors with an eigenvalue greater than 0.5 . They explain $85 \%$ of total variance. Factor 1 has high loadings of Fe (0.962), Ca (0.952), Pb (0.923), Zn (0.918), Mn (0.763) and K (0.742) (Table 2). It explains 58\% of total variance and reflects uptake of metals as nutrients and function of Fe plaque in metal scavenge. Factors 2 and 3 have high loading of $\mathrm{Cu}(0.956)$ and $\mathrm{Cl}(-0.989)$ and explains $14 \%$ and $13 \%$ of total variance, respectively (Table 2). These two factors are individual factors specifically for $\mathrm{Cu}$ and $\mathrm{Cl}$ uptake and transport. In hierarchical clustering analysis (Gotelli and Ellison 2004), the root tissue was analyzed separately for epidermis, vascular tissue and root hair tip. The data treatment was the same as that performed in factor analysis. Elements used for the cluster analysis were $\mathrm{Ca}, \mathrm{Cl}, \mathrm{Cu}, \mathrm{Fe}, \mathrm{K}, \mathrm{Mn}, \mathrm{Pb}$ and $\mathrm{Zn}$. Figure 7a shows three clusters formed in the epidermis. $\mathrm{K}$ and $\mathrm{Cl}$ form one cluster. Fe and $\mathrm{Mn}$, which are then joined in sequence by $\mathrm{Pb}, \mathrm{Zn}$ and $\mathrm{Ca}$, form another cluster. $\mathrm{Cu}$ is independent of other parameters and stays alone. Both $\mathrm{K}$ and $\mathrm{Cl}$ are major ions in sea water and components of salt. Therefore, these two elements cluster together. Fe and Mn form Fe-Mn oxides that can coprecipitate or scavenge other trace metals such as $\mathrm{Pb}$ and $\mathrm{Zn}$. Ca is a major required nutrient for plants. Although $\mathrm{Cu}$ is also a nutrient for the plant growth, the result suggests that the expression of uptake and transport process of $\mathrm{Cu}$ may be different from other trace metals. In the vascular tissue, $\mathrm{K}$ and $\mathrm{Cl}$ form a cluster and then are joined in sequence by $\mathrm{Mn}, \mathrm{Ca}$, Fe and $\mathrm{Zn}$ 
(Figure $7 \mathrm{~b}$ ). $\mathrm{Pb}$ and $\mathrm{Cu}$ loosely form another cluster (Figure 7b). In the root hair tip, $\mathrm{Fe}$ and $\mathrm{Ca}$ cluster together closely and then are joined in sequence by $\mathrm{Pb}, \mathrm{Zn}, \mathrm{Mn}$ and $\mathrm{K}$ (Figure 7c). In the meantime, $\mathrm{Cu}$ and $\mathrm{Cl}$ loosely cluster together (Figure 7c).

\section{Discussions}

Previous studies have shown that rhizosphere in wetlands is a favorable environment for microbial communities (Emerson et al. 1999; Frenzel et al. 1999; Gilbert and Frenzel, 1998; King and Garey 1999; Liu et al., 2004; Perret et al., 2000; Wang and Peverly, 1999). In the rhizosphere, biogeochemical reactions, such as metal oxidation and complexation, most likely occur at the interface between plant roots and rhizosphere soils/sediments. It is understandable that metal concentrations in sediments and plant tissue are usually very different because metals in the sediments are from natural weathering processes (Loring 1991; Taylor and McLennan 1995) or anthropogenic input (Feng et al. 1998; Zhang et al. 2009) while metals in plant tissues are due to plant uptake, translocation and bioconcentration (Gleason et al., 2003; Martin et al. 2006; Qian et al. 2012). Nevertheless, the nutrients required for the plant growth are acquired from the rhizosphere sediments. Due to its large specific surface area, root hair makes absorbing both water and mineral nutrients more efficient. In addition, root hair cells secrete acid $\left(\mathrm{H}^{+}\right)$that solubilizes the minerals into ionic form, making the ions to be taken up easily (MacFarlane and Burchett, 2002; Lasat, 2002; Verbruggen et al., 2009). Therefore, plant root hair can actively uptake metals and other elements from sediments and transport the nutrients in solution through the root xylem to the rest of plant tissue for growth. In some cases, the root hair is even capable of absorbing inorganic nutrients in solution against concentration gradient (Enstone et al. 2003). 
Several early studies discussed the function of Fe plaque in metal transport in plant root system (e.g., St-Cyr and Campbell, 1996; Sundby et al., 1998; Ye et al., 1998; Liu et al., 2004). Because of the high adsorption capacity of Fe-oxides or Fe plaque, which is embedded in wetland plant roots, is considered as a reactive substrate for metal sequestration (Deng et al., 2010; Hansel et al. 2001, 2002; Morrisey and Guerinot, 2009; St-Cyr and Crowder 1990; Otte et al. 1989, 1991; Taylor et al., 1984). This study shows that other trace metals (e.g., Cu, Mn, Pb and $\mathrm{Zn}$ ) besides Fe were also found in the epidermis (Figures 4). The results suggest that these trace metals may be combined with Fe plaque or Fe-oxides and included in the high attenuation substances as shown in Figure 3 due possibly to scavenge by Fe plaque. Although synchrotron CMT measurement in this study cannot identify the chemical composition of the high attenuation substances (Figure 3), the information from synchrotron XRF measurement suggest that Fe must be included in this high attenuation substance (Figure 4). The presence of Fe plaque in the epidermis is further confirmed by synchrotron XANES measurement by setting the energy below and above Fe edge (Figure 5). Because Fe has a relatively higher concentration than other trace metals (Figure 4, Table 1), Fe should have a relatively higher attenuation than the other elements. It is reasonable to believe that this is Fe plaque that is predominantly Fe oxides (St-Cyr and Campbell, 1996; Hansel et al. 2001). In other words, due to the formation of Fe plaque, Fe shows a relatively high concentration in epidermis (Figure 4, Table 1). The accumulation of Cu, $\mathrm{Fe}, \mathrm{Mn}, \mathrm{Pb}$ and $\mathrm{Zn}$ in the epidermis and significant correlation between trace metals $(\mathrm{Cu}, \mathrm{Mn}, \mathrm{Pb}$ and $\mathrm{Zn}$ ) and Fe (Figure 6, $p<0.001$ ) suggest that these trace elements were taken up by the plants and could be scavenged by Fe plaque in the epidermis (Figure 6). In other words, high concentrations of, $\mathrm{Cu}, \mathrm{Mn}, \mathrm{Pb}$ and $\mathrm{Zn}$ in epidermis can be adsorbed by Fe plaque or Fe-Mn 
oxides due to the large specific surface area of iron-oxides (which is often greater than $200 \mathrm{~m}^{2} \mathrm{~g}^{-}$

${ }^{1}$ ) for metal sequestration (Hansel et al. 2001). Therefore, Fe plaque can provide a reactive substrate to scavenge metals (Bargar et al. 1997; Eick et al. 1999). High concentrations of Ca, $\mathrm{Cl}, \mathrm{Cu}$, and $\mathrm{K}$ as well as $\mathrm{Mn}$ and $\mathrm{Zn}$ in vascular tissue can be a result of transportation of these metals by their individual transport protein, as suggested by factor analysis and cluster analysis (Table 2, Figure 7).

\section{Conclusion}

This micro-scale investigation depicted metal concentrations and distributions in Spartina alterfloria root system. The synchrotron XRF measurement showed that the average concentrations of $\mathrm{Cl}, \mathrm{Fe}, \mathrm{Mn}, \mathrm{Pb}$ and $\mathrm{Zn}$ in the epidermis were generally higher than that in the vascular tissue, while the average concentration of $\mathrm{Ca}$ in the epidermis was lower than that in the vascular tissue t. The average concentrations of $\mathrm{Cu}$ and $\mathrm{K}$ in the epidermis and vascular tissue were comparable. Fe plaque was found in the root epidermis, where $\mathrm{Cu}, \mathrm{Mn}, \mathrm{Pb}$ and $\mathrm{Zn}$ showed significant $(p<0.001)$ correlations with Fe possibly as a consequence of metal adsorption by Fe plaque. Although the role of Fe plaque in controlling metal biogeochemical cycle needs further study, the results have shown that the root epidermis can be an important environment to form Fe plaque and control metal uptake and transport by forming less mobile metal species and metal complexes. As a basic scientific research, the results from this study provide useful information on metal transportation and distribution in Spartina alterfloria root system.

\section{Acknowledgements}


This work was supported in part by the State Key Laboratory of Estuarine and Coastal Research Open Research Fund (Ref \#: SKLEC-KF201304) (HF, WZ, LY, WL, YQ), the China Scholarship Council (YQ), and the Margaret and Herman Sokol Foundation (HF). This project was also supported in part by the U.S. Department of Energy, Office of Science, Office of Workforce Development for Teachers and Scientists (WDTS) under the Visiting Faculty Program (VFP) (HF). Use of the NSLS was supported by the U.S. Department of Energy, Office of Science, Office of Basic Energy Sciences, under Contract No. DE-AC02-98CH10886. NSLS X27A was supported in part by the U.S. Department of Energy - Geosciences (DE-FG0292ER14244 to The University of Chicago - CARS). We are also grateful to Professor Elena Maestri, Editor of Environmental Science and Pollution Research, and two anonymous reviewers who offered constructive comments and suggestions on an earlier draft of this paper.

\section{Reference}

Ablett JM, Kao CC, Reeder RJ, Tang Y, Lanzirotti A (2006) X27A-A new hard X-ray microspectroscopy facility at the National Synchrotron Light Source. Nuclear Instruments and Methods in Physics Research A 562:487-494.

Bargar JR, Brown GE, Parks GA (1997) Surface complexation of Pb(II) at oxide-water interface: II. XAFS and bond-valence determination of mononuclear Pb(II) sorptionproducts and surface functional groups on iron oxides. Geochimica et Cosmochimica Acta, 61, 26392652. 
Chen JY, Cheng HQ, Dai ZJ (2007) Compatibility of utilization and protection of tidal flat and wetland: A case study in Shanghai area. China Engineering Science 9, 11-17 (in Chinese with English abstract).

Chen XQ (1998) Changjiang (Yangtze) River Delta, China. Journal of Coastal Research 14, 838858.

Cheng S (2003) Heavy metals in plants and phytoremediation. Environ. Sci. Poll. Res. 10, 335340.

Dai WM, Gu YZ (1990) Accumulation of heavy metal elements in the sediments near Xiqu and Nanqu sewage outlets, Shanghai. Shanghai Environmental Science 9, 38-40 (in Chinese).

Deng D, Wu S-C, Wu F-Y, Deng H, Wong M-H (2010) Effects of root anatomy and Fe plaque on arsenic uptake by rice seedlings grown in solution culture. Environmental Pollution 158, 2589-2595.

Eick MJ, Peak JE, Brady PV, Pesek JD (1999) Kinetics of lead adsorption and desorption on goethite: Residence time effect. Soil Science, 164, 28-39.

Emerson D, Weiss JV, Megonigal JP (1999) Iron-oxidizing bacteria are associated with ferric hydroxide precipitates (Fe-plaque) on the roots of wetland plants. Applied and Environment Microbiology, 65, 2758-2761.

Enstone DE, Peterson CA, Ma F (2003) Root endodermis and exodermis: structure, function, and responses to the environment. J. Plant Growth Reg. 21: 335 - 351.

Feng H, Cochran JK, Lwiza H, Brownawell B, Hirschberg DJ (1998) Distribution of Heavy Metal and PCB contaminants in the sediments of an urban estuary: the Hudson River. Marine Environmental Research, 45, 69-88. 
Feng H, Qian Y, Gallagher FJ, Wu M, Zhang W, Yu L, Zhu Q, Zhang K, Liu C-J, Tappero R (2013) Lead accumulation and association with Fe on Typha latifolia root from an urban brownfield site. Environmental Science and Pollution Research, 20, 3743-3750.

Feng H, Han X, Zhang W, Yu L (2004) A preliminary study of heavy metal contamination in Yangtze River intertidal zone due to urbanization. Marine Pollution Bulletin 49, 910-915.

Frenzel P, Bosse U, Janssen PH (1999) Rice roots and methanogenesis in a paddy soil: ferric iron as an alternative electron acceptor in the rooted soil. Soil Biol. Biochem. 31:421-430.

Gilbert B, Frenzel P (1998) Rice roots and $\mathrm{CH}_{4}$ oxidation: the activity of bacteria, their distribution and the microenvironment. Soil Biology and Biochemistry, 30, 1903-1916.

Gleason SM, Ewel KC, Hue N (2003) Soil redox conditions and plant-soil relationships in a micronesian mangrove forest. Estuarine, Coastal and Shelf Science 56 (2003) 1065-1074

Gotelli NJ, Ellison AM (2004) A Primer of Ecological Statistics, first ed. Sinauer Associates, Sunderland, MA, USA, $492 \mathrm{pp}$.

Hansel CM, Laforce MJ, Fendorf S, Sutton S (2002) Spatial and temporal association of As and Fe species on aquatic plant roots. Environmental Science and Technology, 36, 19881994.

Hansel CM, Fendorf S, Sutton S, Newville M (2001) Characterization of Fe plaque and associated metals on the roots of mine-waste impacted aquatic plants. Environmental Science and Technology, 35, 3863-3868

Hinsinger P, Courchesne F (2008) Biogeochemistry of metals and metalloids at the soil-root interface. In: Violante A, 404 Plant Soil (2009) 321,385-408 
Jones KW, Feng H (2002) Microanalysis of materials using synchrotron radiation. In: Chemical Applications of Synchrotron Radiation, (ed. T. K. Sham). pp. 1010-1054.World Scientific Publishing Company, New Jersey.

Jones KW, Wang J, Chen Y, Yuan Q, Lindquist WB, Beckingham L, Peters CA, Um W, Newman L, Sabo-Attwood T, Tappero R (2013) Tomographic investigations relevant to the rhizosphere In: Anderson SH and Hopmans JW, editors. Soil-Water-Root Processes: Advances in Tomography and Imaging. SSSA Special Publication 61. Madison, Wisconsin; p. 23-39.

Jones K, Feng H, Lanzirotti A, Mahajan D (2005) Synchrotron X-ray microprobe and computed microtomography for characterization of nanocatalysts. Nuclear Instruments and Methods in Physics Research Section B: Beam Interactions with Materials and Atoms, 241, 331-334.

King GM, Garey MA (1999) Ferric iron reduction by bacteria associated with the roots of freshwater and marine macrophytes. Appl. Environ. Microbiol. 65:4393-4398.

Koelmel J, Amarasiriwardena D (2012) Imaging of metal bioaccumulation in Hay-scented fern (Dennstaedtia punctilobula) rhizomes growing on contaminated soils by laser ablation ICP-MS. Environmental Pollution, 168: 62-70.

Lacerda LD, Freixo JL, Coelho SM (1997) The effect of Spartina alterniflora Loisel on trace metals accumulation in inter-tidal sediments. Mangroves and Salt Marshes, 1, 201-209. Lasat MM 2002. Phytoextraction of toxic metals: a review of biological mechanisms. J. Environ. Qual. 31, 109-120. 
Liu M, Hou LJ, Xu SY, Ou DN, Yang Y, Yu J, Wang Q (2006) Organic carbon and nitrogen stable isotopes in the intertidal sediments from the Yangtze Estuary, China. Marine Pollution Bulletin, 52, 1625-1633.

Liu W-J, Zhu Y-G, Smith FA, Smith SE (2004) Do iron plaque and genotypes affect arsenate uptake and translocation by rice seedlings (Oryza sativa L.) grown in solution culture? Journal of Experimental Botany, 55, 1707-1713.

Loring DH (1991) Normalization of heavy-metal data from estuarine and coastal sediments. ICES J Mar Sci 48: 101-115

Lyubenova L, Pongrac P, Vogel-Mikuš K, Mezek GK, Vavpetiič P, Grlj N, Regvar M, Pelicon P, Schröder P (2013) The fate of arsenic, cadmium and lead in Typha latifolia: A case study on the applicability of micro-PIXE in plant ionomics. Journal of Hazardous Materials Journal of Hazardous Materials 248, 371- 378.

MacFarlane GR, Burchett MD (2002) Toxicity, growth and accumulation relationships of copper, lead and zinc in the grey mangrove, Avicennia marina (Forsk.) Vierh. Marine Environmental Research, 54, 65 -84.

Marques APGC, Rangel AOSS, Castro PML (2009) Remediation of heavy metal contaminated soils: phytoremediation as a potentially promising clean-up technology. Crit. Rev. Environ. Sci. Tech. 39, 622-654.

Martin R, Naftel S, Macfie S, Jones K, Feng H, Trembley C (2006) High variability of the metal content of tree growth rings as measured by synchrotron micro x-ray fluorescence spectrometry. X-Ray Spectrometry, 35, 57-62.

McLaughlin MJ, Smolders E, Merckx R (1998) Soil-root interface: physicochemical processes. In: Huang PM, Adriano DC, Logan TJ, Checkai RT (eds) Soil chemistry and ecosystem 
health. Soil Science Society of America, Madison, Wisconsin, USA, pp 233-277 Special Publication no 52

Morrissey J, Guerinot M (2009) Iron uptake and transport in plants: the good, the bad, and the ionome, Chemical Reviews, 109, 4553-4567.

Otte ML, Dekkers MJ, Rozema J, Broekman RA (1991) Uptake of arsenic by Aster tripolium in relation to rhizosphere oxidation. Canadian Journal of Botany, 69, 2670-2677.

Otte ML, Rozema J, Koster L, Haarsma MS, Broekman RA (1989) Iron plaque on roots of Aster tripoliumL.: interaction with zinc uptake New Phytologist, 111, 309-317.

Perret D, Gaillard J, Dominik J, Atteia O (2000) The diversity of natural hydrous iron oxides. Environmental Science and Technology, 34, 3540-3546.

Punshon T, Guerinot M, Lanzirotti A (2009) Using synchrotron X-ray fluorescence microprobes in the study of metal homeostasis in plants, Annals of Botany, 103, 665-672.

Qian Y, Gallagher FJ, Feng H, Wu M (2012) A geochemical study of toxic metal translocation in an urban brownfield wetland. Environmental Pollution,166, 23-30.

Rotkittikhum P, Kruatrachue M, Chaiyarat R, Ngernsansaruay C, Pokethitiyook P, Paijitprapaporn A, Baker AJM (2006) Uptake and accumulation of lead by plants from the Bo Ngam lead mine area in Thailand. Environmental Pollution, 144, 681-688.

St-Cyr L, Crowder AA (1990) Manganese and copper in the root plaque of Phragmites australis (Cav.) Trin. ex Steudel. Soil Sci 149: 191-198.

St-Cyr L, Campbell PGC (1996) Metals (Fe, Mn, Zn) in the root plaque of submerged aquatic plants collected in situ: Relations with metal concentrations in the adjacent sediments and in the root tissue. Biogeochemistry 33, 45-76. 
Sundby B, Vale C, Caçador I, Catarino F, Madureira MJ, Caetano M (1998) Metal-rich concretions on the roots of salt marsh plants: mechanism and rate of formation. Limnology and Oceanography, 43, 245-252.

Sutton SR, Bertsch PM, Newville M, Rivers ML, Lanzirotti A, Eng PJ (2002) Microfluorescence and microtomography analyses of heterogeneous earth and environmental materials. In: Fenter P A, Rivers ML, Sturchio NC, Sutton SR (eds) Applications of synchrotron radiation in low-temperature geochemistry and environmental science, Vol. 49. Chantilly, VA: Mineralogical Society of America, 429-483.

Tangahu BV, Abdullah SRS., Basri H, Idris M, Anuar N, Mukhlisin M (2011) A review on heavy metals (As, $\mathrm{Pb}$, and $\mathrm{Hg}$ ) uptake by plants through phytoremediation. International Journal of Chemical Engineering, article ID 939161, 31 pages.

Taylor GJ, Crowder AA, Rodden R (1984) Formation and morphology of an iron plaque on the roots of Typha latifolia L. grown in solution culture American Journal of Botany,71: 666675.

Taylor SR, McLennan SM (1995) The geochemical evolution of the continental crust. Reviews in Geophysics 33, 241-265.

Tripathi RD, Tripathi P, Dwivedi S, Kumar A, Mishra A, Chauhan PS, Norton GJ, Nautiyal CS (2014) Roles for root iron plaque in sequestration and uptake of heavy metals and metalloids in aquatic and wetland plants. Metallomics 6, 1789-1800.

Verbruggen N, Hermans C, Schat H (2009) Molecular mechanisms of metal hyperaccumulation in plants, New Phytol. 181, 759-776.

Wang TG, Peverly JH (1999) Iron oxidation states on root surfaces of a wetland plant (Phragmites australis). Soil Science Society of America Journal, 63, 247-252. 
Wang J, Chen YK, Yuan Q, Tkachuk A, Erdonmez C, Hornberger B, Feser M (2012) Automated markerless full field hard x-ray microscopic tomography at sub-50nm 3-dimension spatial resolution. Applied Physics Letters 100, 143-107.

Wang J, Chen-Wiegart'Y K, Wang J (2013) In situ chemical mapping of a lithium-ion battery using full-field hard X-ray spectroscopic imaging. Chemical Communications, 49, 64806482

Wang J, Chen-Wiegart Y K, Wang J (2014a) In Situ Three-Dimensional Synchrotron X-Ray Nanotomography of the (De)lithiation Processes in Tin Anodes. Angewandte Chemie International Edition, 53 (17), 4460-4464.

Wang J, Chen-Wiegart YK, Wang J (2014b) In operando tracking phase transformation evolution of lithium iron phosphate with hard X-ray microscopy, Nature Communications 5, doi:10.1038/ncomms5570

Weis JS, Weis P (2004) Metal uptake, transport and release by wetland plants: implications for phytoremediation and restoration, Environment International, 30, 685-700.

Williams TP, Bubb JM, Lester JN (1994) Metal accumulation within salt marsh environments: A review. Marine Pollution Bulletin, 28: 273-290.

Windham L, Weis JS, Weis P (2003) Uptake and distribution of metals in two dominant salt marsh macrophytes, Spartina alterniflora (cordgrass) and Phragmites australis (common reed). Estuarine, Coastal and Shelf Science 56, 63-72.

Wu H, Zhu JR, Choi BH (2010) Links between saltwater intrusion and subtidal circulation in the Changjiang Estuary: A model-guided study. Cont. Shelf Res., 30, 1891-1895. 
Ye ZH, Baker AJM, Wong MH, Willis AJ (1998) Zinc, lead and cadmium accumulation and tolerance in Typha latifolia as affected by iron plaque on the root surface. Aquatic Botany, 61, 55-67.

Zhang W, Feng H, Chang J, Qu J, Xie H, Yu L (2009) Heavy metal contamination in surface sediments of Yangtze River intertidal zone: an assessment from different indexes . Environmental Pollution, 157, 1533-1543.

Zhang W, Yu L, Hutchinson SM, Xu S, Chen Z, Gao X (2001) China's Yangtze Estuary: I. Geomorphic influence on heavy metal accumulation in intertidal sediments. Geomorphology 41, 195-205. 


\section{Figure Legends}

Figure 1. Map showing the sampling site on the north shore of Chongming Island in the Yangtze River intertidal zone.

Figure 2. Optical images showing the structure of Spartina alterfloria root cross-sections: a) 4-1 tip section, 2) 4-2 tip section, and 3) 4-1 basal section. Roots 4-1 and 4-2 are replicate samples. The thickness of the cross-sections is $50 \mu \mathrm{m}$. These thin cross-section samples are prepared for synchrotron XRF measurement for metal concentrations and distributions. The areas framed in the root epidermis, vascular tissue and hair tip are extracted for data analysis.

Figure 3. Two and three dimensional reconstructed images of synchrotron X-ray computed tomography (CMT) measurement on Spartina alterfloria root: a) 2D image of Spartina alterfloria root cross-section; b) profile of attenuation along the cross-section labeled in the 2D image; and c) 3D image of Spartina alterfloria root with root hair showing.

Figure 4. Metal concentrations and distributions in Spartina alterfloria root cross-sections. 4-1 tip and 4-2 tip are replicates of the root tip samples from two Spartina alterfloria root samples. 4-1 tip and 4-1 bottom are the tip and basal sections of the same root sample. The extension in 4-1 bottom section is the root hair.

Figure 5. Synchrotron X-ray absorption near edge structure (XANES) measurement confirms spatial distribution of Fe plaque in the epidermis of Spartina alterniflora root: (a) Fe XANES image taken at $7092 \mathrm{eV}$ (below $\mathrm{Fe}^{2+}$ pre-edge); (b) Fe XANES image taken at $7192 \mathrm{eV}$ (above $\mathrm{Fe}^{3+}$ pre-edge); and (c) Fe XANES spectrum of a point in the center of Fe plaque as indicated by an arrow. The "shadows" in (a), where Fe plaque was found, indicates the absorption of other 
metals, such as $\mathrm{Mn}, \mathrm{Cu}$ and $\mathrm{Ni}$, whose pre-edges are below Fe pre-edge. The results suggest the metal scavenge by Fe plaque or Fe-Mn oxides.

Figure 6. Significant correlations $(p<0.001)$ of $\mathrm{Cu}, \mathrm{Mn}, \mathrm{Pb}$ and $\mathrm{Zn}$ with Fe in all the sub-areas within the epidermis of Spartina alterfloria roots.

Figure 7. Results of the cluster analysis performed on the root epidermis, vascular tissue and hair tip, respectively (Linkage: single linkage method (nearest neighbor); Distance: Pearson correlation coefficient). 